\title{
REVIEW OF THE BOOK "THE LEGAL AND ECONOMIC ASPECTS OF ASSOCIATIONS AND AGRICULTURAL PRODUCERS IN SELECTED COUNTRIES OF THE WORLD" BY ANETA SUCHOŃ (EDITOR)
}

\author{
RECENZIA KNIHY \\ “PRÁVNE A EKONOMICKÉ ASPEKTY ASOCIÁCIÍ \\ A POL'NOHOSPODÁRSKYCH PRODUCENTOV \\ VO VYBRANÝCH KRAJINÁCH SVETA" \\ OD ANETY SUCHOŃ (EDITOR)
}

\author{
Paul RICHLI
}

Prof. UAM Dr. hab. Aneta Suchoń presents with this publication a very remarkable book about the legal form of the cooperative and the functions of the cooperative in agriculture. She has succeeded in winning recognised experts from several countries for the project. Eight authors have each written a country report. One author contributes a fundamental article on agricultural organisation law. And one author has written an overview article on the worldwide development of the agricultural cooperative movement. In addition to the country report on Poland, the editor herself presents the introduction to the book and an overview article on the emergence and development of agricultural cooperative law worldwide and in Europe.

At the beginning of her introduction, Aneta Suchon characterises agriculture in a concise manner with the following words, thereby simultaneously justifying the great need for cooperation in agriculture within the framework of cooperatives (p. 13): «Agriculture, which fulfils important economic, social and spatial functions, is a significant branch of the economy. Its chief aims focus on the production of food and raw resources for various branches of the industry, and more broadly speaking, on the supply of public goods. At the same time, there is a high level of financial uncertainty for agricultural producers, due to, for example, the relatively high costs associated with agricultural activity, the price changes of agricultural products and the impact of weather conditions. In addition, agricultural producers, especially European ones, have to meet more and more requirements related to areas such as environmental protection, public health, and animal health. Taking into account the high degree of financial uncertainty experienced by agricultural producers, associated with the relatively high costs related to agricultural activities, the collective action of farmers is necessary to reduce the costs of agricultural production, achieve higher prices for agricultural products and increase their competitiveness in the market.»

Specifically for the USA, Aneta Suchoń explains (p. 16) that the majority of the approximately two million farmers belong to one or more cooperatives. Around 30 per cent of all agricultural products are sold through about 3000 manufacturing cooperatives. In this context, it should be mentioned that in the USA, a special antitrust law for agricultural cooperatives, especially in the dairy sector, has been in force for around 100 years, which privileges cooperatives by offering farmers opportunities to build countervailing power against the highly concentrated buyer side (see Paul Richli/Christian Busse, Competition rules in agriculture, General report of Commission I, in: CEDR [ed.], Agriculture and Competition, XXIX European Congress and Colloquium of Rural Law, Baden-Baden 2019, p..133 ff.). According to Suchon, there are around 22,000 agricultural cooperatives in the European Union, and their total turnover exceeds EUR 347 billion. They have more than a 50\% share in deliveries of the means of agricultural production and more than $60 \%$ in the purchasing, processing and marketing of agricultural products.

The European Union has also recognised that it is essential to give farmers more opportunities to organise countervailing power against the highly concentrated buyer side, which has been achieved with Regulation (EU) No 1308/2013. This puts European antitrust law into perspective, especially for cooperatives. Suchoń rightly cites Section 131 of its Preamble which says (S. 17): «Producer organisations and their associations can play useful roles in concentrating supply, in improving the marketing, planning and adjusting of production to demand, optimising production costs and stabilising producer prices, carrying out research, promoting best practices and providing technical assistance, managing by-products and risk manage-

\footnotetext{
University of Lucerne, Switzerland
} 
ment tools available to their members, thereby contributing to strengthening the position of producers in the food chain.» The relativisation under cartel law is expressed even more clearly in Section 139, where it is stated: «In order to ensure the viable development of production and thus a fair standard of living for producers in the beef and veal and olive oil sectors, as well as for producers of certain arable crops, their bargaining power vis-à-vis downstream operators should be strengthened.»

Aneta Suchon rightly emphasises that the cooperative is not only an object of study from a legal point of view, but also from a cognitive, social and economic point of view. Thus, in the EU, social policy, employment and regional development are also affected, all of which also have an impact on cooperatives (p. 18 f.).

At the end of the introduction (p. 21), Aneta Suchon writes about the methodology that she did choose for the work: «The basic research method involved the dogmatic analysis of normative texts, which is a characteristic feature of a lawyer's work. In the first place, the legislative acts concerning agricultural law and cooperative law were examined. The analysis of legislative acts in the field of civil, administrative and financial law accounted for the agricultural aspect.»

In her overview article, Aneta Suchoń presents very interesting explanations and reflections on the origin and the development of legal regulations governing associations of agricultural producers in the world, with particular emphasis on cooperatives in Europe, in which she also provides insights into the development in countries that are not dealt with individually in the book. These include Denmark, the Netherlands and the United Kingdom (p. 23 ff.). One focus is on outlining the influence of the EU on the development of cooperatives (p. $36 \mathrm{ff}$.).

The description of cooperative law in the individual countries usually covers at least organisation, capitalisation and membership. National legal peculiarities are quite numerous. Only a few elements are mentioned hereafter:

In the contribution for Argentina by Prof. Alfredo Gustavo Diloreto, other forms of companies, namely corporations, are mentioned in addition to the cooperative, such as the limited liability company and the joint-stock company, but also other forms of cooperation such as the cooperation groupings and cooperation consortia. Likewise, there are cooperations in various forms on a contractual basis (p. 46 ff.).

According to the contribution by Prof. Catherine Del Cont and Allison Macé, PhD student, the legal forms for agricultural production in France have taken a particularly rich and differentiated form (p. $61 \mathrm{ff}$.). In addition to the cooperative as a good form of co-operation, various legal forms are available for individual farms. Furthermore, producer organisations and contracting play an important role in the field of co-operation. France has a particularly strong interest in weakening antitrust law for co-operations among agricultural producers. Evidence of this is the «Endives» case, which has become a leading case by the European Court of Justice with regard to the extremely important agricultural antitrust law for farmers (on this, see for example Rudolf Mögele/Oliver Sitar, Neue Entwicklungen des landwirtschaftlichen Wettbewerbsrechts der EU im Lichte des Endivienurteils des EuGH und der sog. Omnibusnovelle, Agrar- und Umweltrecht 2018, p. 362 ff.).

According to the article by Prof. José Martinez, Germany has a dogmatically well-developed law for agricultural co-operation (p. 81 ff.). The spectrum ranges from loose cooperation to firm connections under company law and participations in the form of cooperatives and producer organisations. For larger co-operations, the so-called Raiffeisengenossenschaften have become very important. Of considerable interest are special provisions for certain product areas.

Of particular interest is the contribution by Dr. Christian Busse entitled «Quo vadis Agrarorganisationsrecht? - A brief consideration in six chapters», which deals with basic questions of development in Germany and the EU (p. 105 ff.).

The presentation of the Italian legal situation by Prof. Irene Canfora shows the big influence of the requirements of EU law. However, it seems that not all possibilities of making EU law more flexible are exhausted. Producer organisations are limited to the «marketing role», which hinders other functions and activities of such organisations (p. 121 ff.).

The legal situation in Poland, described by Prof. Aneta Suchon, is of particular interest not least because there are still more than one million agricultural holdings there. Structural adjustment is slow. Cooperation is therefore particularly urgent. In the dairy sector, there are more than 100 dairy cooperatives today. In addition, the Farmers Cooperatives, the Agricultural Producer Groups and the Agricultural producer organisations, the Social-professional farmers' organisations, the Industry associations as well as the unique Country housewives associations are described in more detail (p. 133 ff.).

As far as Slovakia is concerned, according to the study by Jarmila Lazíková, PhD, Doc. JUDr. Ing., producer organisations are important because they allow economies of scale to be achieved and thus strengthen the market position of farmers (p. 157 ff.). The presentation of the historical development of cooperative law since 1845 is interesting. Between 1948 and 1989, the cooperative idea remained, but underwent a transformation. Today, agricultural cooperatives are structured as producer organisations in order to improve the market position of their members. However, it can be read that the economic reach of producer organisations is so small that they are not subject to EU competition law, but only to national antitrust law.

In Slovenia, according to the contribution by Franci Avsec, $\mathrm{PhD}$, producer organisations are well established and enjoy considerable trust among producers (p. 177 ff.). Agricultural co-operation can be organised in various legal forms, not only as cooperatives, although this form is often chosen. A historical insight is that the current period began in 1992 with the enactment of the Cooperatives Act. Major challenges were posed by accession to the EU in 2004.

Spain has, according to the report of Prof. Trinidad Vázquez Ruano, the special feature that the cooperative is already anchored at the constitutional level (p. 195 ff.). Regulation takes place at three levels: EU, national level and communities. This embedding is well shown, as are the forms of cooperative integration. The highest organisational level is the «grupos cooperativos». Mergers of cooperatives are also dealt with.

Maria Zuba-Ciszewska, PhD, presents her contribution under the title «The role of agricultural cooperative movement worldwide - economic comments» (p. 213 ff.). It is based primarily on data from the International Cooperative Asso- 
ciation (ICA) and Euricse. According to this, there are currently three million cooperatives, which provide work for 10 per cent of the world's employed people. About 12 per cent of the world's population, spread over almost all countries, are involved in cooperatives. Among the cooperatives, agricultural cooperatives are particularly significant. In addition, there are data from «Cooperatives Europe», which represents 176,000 European cooperatives from all economic sectors. Around 57 percent of the largest agricultural cooperatives are active in Europe. According to the author, the main purpose of cooperatives is to improve the social situation of their members and their families.

The Final considerations and de lege ferenda remarks (p. 231 ff.) emphasise the importance of cooperatives for strengthening the competitive (countervailing) power of agricultural producers. Cooperatives are popular in all the countries studied. They are suitable for co-operation between smaller and small farms, especially family farms. In the states with an unbroken market economy, cooperatives have been present without interruption for almost two hundred years. But even in the states with a temporary socialist order, the development has not been interrupted in the long term. The editor summarises the presentations on the individual countries well and also makes certain considerations de lege ferenda.

The present work is a significant enrichment of the agricultural law literature. In addition to providing evidence of interesting regulations in individual countries, it offers a good basis for additional legal comparison. The reading is highly recommendable, especially for lawyers and other experts in agricultural organisations, agricultural offices and for farmer advisors.

Contact address/ Kontaktná adresa

\section{Dr. Paul Richli}

full professor emeritus for public law, agricultural law and theory of legislation at the University of Lucerne

e-mail: paul.richli@unilu.ch 